Vegetables reconstituted after electronic dehydration may be cooked and served in the same way as fresh vegetables. Reconstitution is accomplished by soaking the vegetables in water. They then return to their original colour and consistency and retain their normal taste and aroma. The vitamin content of electronically dehydrated vegetables is especially high, due apparently to the much shorter processing time. The exact method of dehydration cannot be disclosed at present. Briefly, however, 80 per cent of the moisture is removed by conventional methods, leaving the vegetables pliable but without formation of 'case hardening'. The vegetables are then compressed into bricks and the remaining moisture is removed electronically, after which they are ready to be wrapped in paper, wax coated, packed and shipped. The whole procedure is well adapted to automatic straight line production. Laboratory results show that one pound of water may be removed electronically with less than one $\mathrm{kWh}$. of energy, a figure which is economically good in comparison with other methods. In addition to vegetables, dried whole milk also has had its moisture content reduced electronically from two per cent to one per cent. This small difference makes it possible to ship dried whole milk without danger of its butter fat content becoming rancid. Unlike dried skim milk, dried whole milk can be reconstituted to be as palatable and nutritious as fresh milk. Apart from the importance of this electronic dehydration achievement, the process represents another of the many outgrowths of fundamental research and development in industry. Electronic dehydration of foodstuffs was undertaken by the Federal Telephone and Radio Corporation as a co-operative and nonremunerative project to aid in the war effort.

\section{Recent Advances in Public Health Measures}

From the Fight Against Disease, 31, 1943, issued by the Research Defence Society, we learn that six anti-vivisection societies reported in the last pre-war year an income of more than $£ 50,000$. The Research Defence Society, on the other hand, got along vigorously in 1942 on about $£ 500$. Its report for 1942 gives interesting details about the prevention of a wide outbreak of smallpox when it appeared in Scotland in May 1942. Some of us who had to pass through Glasgow in July of that year remember well the encouraging spectacle of the people crowding to the vaccination centres. About 500,000 people were vaccinated and by July 31 , thirty days after the vaccination campaign had kegun, the last case of smallpox was reported. The report also deals with the remarkable results of immunization against diphtheria. There must be few intelligent people who will refuse their children this inestimable benefit. If any are still disposed to do so, they should read W. T. Russell's report, published by the Medical Research Council, on the epidemiology of diphtheria during the last forty years.

The Ministry of Health, Ministry of Information and Central Council for Health Education send us samples of the publicity material issued by them for use in the campaign against diphtheria. Sir Wilson Jameson calculates that diphtheria kills someone in Great Britain every three or four hours and every twenty minutes sends a child to hospital. The number of children who have been protected is not enough. Children under five are most likely to suffer. It is astonishing that parents can still fail to take their children to receive this safe, simple treatment, obtainable free through any medical officer of health. It should be obtained now, before the winter comes.

The Medical Research Council sends us another valuable memorandum (War Memorandum No. 10) entitled the "Medical Use of Sulphonamides". This deals with the chemistry, pharmacology, dosage, toxicity and supply of these drugs and with the treatment of specific infections with them. They have been given so many names that the lists here given of the alternative names of each compound will help to prevent confusion. Appendixes deal with the estimation of the concentration of sulphonamides in the body fluids, with tests for sulphonamideresistance in bacteria and with the sterilization of sulphanilamide powder.

\section{Authority in Medicine}

IN the Linacre Lecture delivered at St. John's College, Cambridge, on May 6, 1943, Prof. Major Greenwood, after a graceful tribute to previous lecturers including Sir Thomas Watson, Sir Humphry Rolleston, Sir George Newman and Dr. W. W. C. Topley, dealt at length with the doctrine of Galen, with whom Linacre was familiar, and particularly his work on epidemiology, general hygiene and medical psychology. Prof. Greenwood regards Galen's epidemiological influence as bad because he overrated the creative power not of Nature but of his own intelligence, and never considered alternative hypotheses as was done by John Graunt fifteen hundred years later. Galen's work on personal hygiene, which Prof. Greenwood regards as the most readable of his books, contains an admirable description of practical dietetics, physical training and the Horation philosophy of life. As regards medical psychology, according to Prof. Greenwood, Galen was in advance of any medical writers of the Renaissance. Passing on to the subject of experimental epidemiology, in which he was associated with Dr. Topley for more than fifteen years, Prof. Greenwood points out that in acute infectious diseases like typhus pure laboratory work has created an applied science of immunology which owes nearly everything to the experimental method. The lecture ends with an encomium of the late Sir Walter Fletcher, secretary of the Medical Research Council, of whom he says that "he fought for and secured a scientific freedom in state-aided medical research".

\section{Archæological Research in Ulster}

In 1935 the Government of Northern Ireland agreed to pay 60 per cent of the wages of unemployed labourers engaged for the purpose of archæological excavation, up to a total sum of $£ 500$. Later the percentage was raised to 80 . This method of dealing with the then acute problem of unemployment was to some extent copied from that already in operation in the Irish Free State. As a result, much valuable excavation was undertaken in 1935 and succeeding years, and important information has come to light. More particularly have the various museums and archæological societies, which have taken advan. tage of the opportunity, concentrated on the study of the North Irish megalithic monuments. Ireland's geographical position is such that the island was a very important area in the days when the megalith builders were wandering about parts of western Europe. Northern Ireland has its full share of these 